\title{
ARTICLE \\ Folk Medicinal Plants Used by Local Herbalists in and around Rajshahi Metropolitan City, Bangladesh
}

\author{
A.H.M. Mahbubur Rahman*
}

Plant Taxonomy Laboratory, Department of Botany, University of Rajshahi, Rajshahi-6205, Bangladesh

\begin{tabular}{|c|c|}
\hline ARTICLE INFO & ABSTRACT \\
\hline Article history & \multirow{9}{*}{$\begin{array}{l}\text { Folk medicinal plants used by local herbalists in and around Rajshahi } \\
\text { metropolitan city were recorded. The study include } 111 \text { medicinal plants } \\
\text { used to cure various diseases such as diarrhea, diabetes, toothache, fe- } \\
\text { ver, worm, snake-bite, blood disease, cough, menstrual disease, wound, } \\
\text { itches, chicken pox, constipation, dysentery, eczema, piles, sex problems, } \\
\text { skin diseases, headache, anemia, burning sensation, bronchitis, paralysis, } \\
\text { jaundice, asthma,etc. Finally, this study shows that traditional medicine } \\
\text { really contributes to the health care of the population and deserves to be } \\
\text { accompanied. The identified medicinal plants will guide future research } \\
\text { into natural substances for the development of improved traditional medi- } \\
\text { cines. }\end{array}$} \\
\hline Received: 1 April 2021 & \\
\hline Accepted: 20 April 2021 & \\
\hline Published Online. 15 Mav 2021 & \\
\hline Published Unlıne: 15 May 2021 & \\
\hline Keywords: & \\
\hline Folk medicinal plants & \\
\hline Herbal drug development & \\
\hline Rajshahi & \\
\hline
\end{tabular}

\section{Introduction}

Traditional medicine as identified by the World Health Organization (WHO) "Total of knowledge, skills, and practices based on the theories, beliefs, and experiences indigenous to different cultures, whether explicable or not, used in the maintenance of health as well as in the prevention, diagnosis, improvement of treatment of physical and mental illness" ${ }^{[16]}$.

The fact has proved that the ethnic communities around the world owning their own culture based on that they developed their system of medical practices, which are being addressed as folk and ethno-medicines. There are numerous medicinal plants available in their surroundings and those herbs are being used by the tribal community as medicine for curing their diseases. The local people lived in a forest environment for many generations and devel-

oped their knowledge of the flora and fauna of the forest that is known as folk or indigenous knowledge. At the same time, they have developed folk beliefs based on traditional practices that helped them in curing various forms of diseases. The beliefs and practices related to curing disease which are based on unwritten knowledge are carried from generation to generation through the practitioners ${ }^{[7]}$. Various research work on traditional medicinal plants was carried out in Bangladesh by ${ }^{[2,4,5,11,12,15,17-31]}$. The present document was undertaken to record the traditional medicinal plants used by local herbalists in and around Rajshahi metropolitan city, Bangladesh.

\section{Materials and Methods}

\subsection{Study Area}

Rajshahi is a metropolitan city, and a major urban,

*Corresponding Author:

A.H.M. Mahbubur Rahman,

Plant Taxonomy Laboratory, Department of Botany, University of Rajshahi, Rajshahi-6205, Bangladesh;

Email:drrahmanahmm@ru.ac.bd 
commercial and educational centre of Bangladesh. It is also the administrative seat of eponymous division and district. Located on the north bank of the Padma River, near the Bangladesh-India border, the city has a population of over 763,952 residents. The city is surrounded by the satellite towns of Nowhata and Katakhali, which together build an urban agglomeration of about 1 million populations. Arguably Rajshahi is the most clean and green among the cities in Bangladesh ${ }^{[3]}$.

\subsection{Methodology}

The present investigation focused on traditional medicinal plants in and around Rajshahi metropolitan city, Bangladesh during July 2017 to December 2018 to collect information on the medicinal uses of different plant species. A total of 111 species belonging to 102 genera under 55 families were recorded. Medicinal information was obtained through semi-structured interviews with knowledgeable traditional healers. A total of 19 local herbalists having an age range 32-78 years were interviewed using semi-structured interviewed method ${ }^{[32]}$ Plant parts with either flower of fruits collected using traditional herbarium techniques to make voucher specimens for documentation and voucher specimens have been preserved at Herbarium of Rajshahi University.

\subsection{Identification}

Collected specimens have been critically examined, studied and identified. Identifications have been confirmed by consulting standard literatures ${ }^{[8,14,1]}$. Nomenclature has been updated following recent literature ${ }^{[1,9,13]}$.

\section{Results and Discussion}

Folk medicinal plants used by local herbalists in and around Rajshahi metropolitan city, Bangladesh was carried out from July 2017 to December 2018. A total of 111 plant species under 102 genera and 55 families were recorded. Distribution of angiosperm species in the families shows variation. The family Fabaceae and Euphorbiaceae represented by 6 species each. Each of Moraceae and Apocynaceae is represented by 5 species. Each of Asteraceae and Amaranthaceae is represented by 4 species. Each of Lamiaceae, Acanthaceae Zingiberaceae, Liliaceae, Piperaceae Malvaceae, Caesalpiniaceae, Combretaceae, Rutaceae, Solanaceae and Verbenaceae is represented by 3 species. Each of Lauraceae, Cucurbitaceae, Mimosaceae, Myrtaceae, Anacardiaceae, Oxalidaceae, Apiaceae, Convolvulaceae, Araceae and Poaceae is represented by 2 species. A single species in each was recorded by 30 families (Table 1). Out of 111 species, $41.73 \%$ species were used in herbs, followed by $17.92 \%$ shrubs, $7.79 \%$ climbers and $31.27 \%$ trees (Figure 1). For each species local name, scientific name, family, habit, ailments, treatment process and part (s) used are provided.

Use of plant parts as medicine shows variation. Leaves $(49.89 \%)$ are the leading part used in a majority of medicinal plans followed by Bark (15.92\%), fruits (19.70\%), root $(17.32 \%)$, seed $(12.88 \%)$, stem $(8.68 \%)$, whole plants $(16.82 \%)$, flowers $(3.53 \%)$, leaf stalk $(0.99 \%)$, rhizome (2.53\%), gum $(3.53 \%)$, petiole $(2.53 \%)$, tuber $(1.65 \%)$, bulb $(1.65 \%)$, latex $(1.65 \%)$, bud $(0.99 \%)$ (Figure 2$)$. The survey has also recorded 66 categories of uses of 111 medicinal plants. Out of 66 diseases, fever $(20.82 \%)$, dysentery $(18.11 \%)$, cough $(11.83 \%)$, diarrhea $(9.99 \%)$, asthma $(8.32 \%)$, diabetes $(7.89 \%)$, skin disease $(7.50 \%)$ and jaundice $(6.53 \%)$ (Figure 3$)$.

The result of this information showed that these local people of study area still depend on medicinal uses of plants for the treatment of burning sensation, diabetes, bronchitis, weakness, insects and snake bite, high blood pressure, asthma, passing of semen, gonorrhea, skin diseases, jaundice, headache, glandular swelling, diarrhea, acidity, dry cough, cancer, dysentery, scabies, menstrual disorder, tumors, leucoderma, catarrhal fever, chronic fever, malarial fever, toothache, burning wounds, stomachic, stomachache, piles, fever, epilepsy, gout, rheumatism, traumatic injury, abortion, vomiting, bleeding gums, ulcer, anemia, ring worm, hiccup, pneumonia, gastritis, tuberculosis, arthritis, heart disease, abdominal pain, hypertension, paralysis, constipation, baldness, sore, dyspepsia, chicken pox, pain, pyorrhea, eczema, cholera, flatulence, scurvy, intoxication, indigestion, whooping cough, digestive system disorders, liver disorders, intestinal worms, worms, gastrointestinal disorders, edemas, alterative and attendant, wound and injury, menstruation, cold, lung infection, dysuria, edema, bleeding, heavy bleeding, kidney, eye inflammation, boils, mouth freshener, bruises, high cholesterol, dry skin, hepatitis, hair fall, cough and many types of diseases.

Most of the species were used for the treatment of different diseases are Polyalthia longifolia, Cinnamomum tamala, Litsea glutinosa, Peperomia pellucida, Piper betel, Piper longum, Kalanchoe pinnata, Nigella sativa, Nymphaea nouchali, Tinospora cordifolia, Argemone mexicana, Ficus religiosa, Ficus benghalensis, Ficus hispida, Ficus racemosa, Artocarpus heterophyllus, Boerhaavia diffusa, Amaranthus spinosus, Amaranthus viridis, Achyranthes aspera, Enhydra fluctuans, Basella alba, Glinus oppositifolius, Polygonum hydropiper, Aborma augusta, Bombax ceiba, Hibiscus rosa-sinensis, Abelmoschus esculentus, Sida cordifolia, Coccinia grandis, Momordica 
charantia, Brassica napus, Moringa oleifera, Mimusops elengi, Diospyros malabarica, Acacia nilotica, Mimosa pudica, Cassia fistula, Tamarindus indica, Saraca indica, Cajanus cajan, Lablab purpureus, Erythrina variegata, Dalbergia sissoo, Butea monosperma, Clitoria ternetea, Lowsonia inermis, Punica granatum, Psidium guajava, Syzygium cumini, Terminalia arjuna, Terminalia chebula, Terminalia belerica, Acalypha indica, Euphorbia hirta, Jatropha gossypifolia, Phyllanthus emblica, Phyllanthus reticulatus, Ricinus communis, Cissus quadrangularis, Litchi chinensis, Mangifera indica, Spondias pinnata, Azadirachta indica, Citrus aurantifolia, Aegle marmelos, Feronia limonia, Averrhoa carambola, Oxalis corniculata, Centella asiatica, Coriandrum sativum, Swertia chirata, Catharanthus roseus, Rauvolfia serpentina, Alostonia scolaris, Nerium indicum, Carissa carandus, Calotropis procera, Datura metel, Solanum nigrum, Capsicum frutescens, Ipomoea aquatica, Ipomoea batatas, Heliotropium indicum, Clerodendrum viscosum, Vitex negundo, Lantana camara, Ocimum sanctum, Leucas aspera, Leonurus sibiricus, Nyctanthes arbortristis, Andrographis paniculata, Justicia gendarussa, Adhatoda vasica, Tridax procumbens, Wedelia chinensis, Tagetes erecta, Eclipta alba, Areca catechu, Colocasia esculenta, Alocasia indica, Cyperus rotundus, Cynodon dactylon, Saccharum officinarum, Ananas comosus, Musa sapientum, Curcuma longa, Zingiber officinale, Amomum subulantum, Allium cepa, Allium sativum, Aloe barbadensis (Table 1). The collected information is comparable with the result of other studies in Bangladesh like ${ }^{[2,4,5,10,11,12,15,6,17-31]}$.

Table 1. Investigated medicinal plants used by the local herbalists in the study area

\begin{tabular}{|c|c|c|c|c|}
\hline Bangla name & Botanical name and Family name & Habit & Parts Used & Ailments \& Treatment Process \\
\hline Ada & $\begin{array}{l}\text { Zingiber officinale Roscoe } \\
\quad \text { (Zingiberaceae) }\end{array}$ & Herb & Rhizome & $\begin{array}{l}\text { Indigestion: Rhizome powder is taken internally }{ }^{[2]} \text {. Cold and } \\
\text { Cough: Corm juice is taken }{ }^{[5]} \text {. Cattarhal fever: Ginger juice } \\
\text { mixed with leaf juice of Ocimum sanctum and honey is taken } \\
\text { orally }{ }^{[29]} \text {. Gout: Warm paste of rhizome with cotton seed is } \\
\text { applied externally }{ }^{[2]} \text {. }\end{array}$ \\
\hline Akando & $\begin{array}{l}\text { Calotropis procera (Aiton) } \\
\text { W.T. Aiton } \\
\text { (Asclepiadaceae) }\end{array}$ & Shrub & Leaf & $\begin{array}{l}\text { Arthiritis: Warm mustard oil with salt and leaves are taken } \\
\text { externally }{ }^{[26]} \text {. Paralysis: Warm leaf paste is taken externally } \\
{ }^{28]} \text {. Rheumatism: Gums mixed with Brassica napus oil used } \\
\text { internally }{ }^{[22]} \text {. }\end{array}$ \\
\hline Alach & $\begin{array}{l}\text { Amomum subulatum Roxb. } \\
\text { (Zingiberaceae) }\end{array}$ & Herb & Seed, Fruit, pod & $\begin{array}{l}\text { Mouth freshener, Nausea, motion sickness \& Cough: Pow- } \\
\text { der of seeds is taken orally }{ }^{[10,11]} \text {. }\end{array}$ \\
\hline Anarosh & $\begin{array}{l}\text { Ananas comosus (L.) Merr. } \\
\text { (Bromeliaceae) }\end{array}$ & Herb & $\begin{array}{l}\text { Flower, Leaf, } \\
\text { Fruit }\end{array}$ & $\begin{array}{l}\text { Fever: Fruits are taken internally }{ }^{[17]} \text {. Abortion: Young flower } \\
\text { extract is taken internally }{ }^{[21]} \text {. }\end{array}$ \\
\hline Apang & $\begin{array}{l}\text { Achyranthes aspera } \mathrm{L} \text {. } \\
\quad \text { (Amaranthaceae) }\end{array}$ & Herb & $\begin{array}{l}\text { Stem, Leaf, } \\
\text { Root }\end{array}$ & $\begin{array}{l}\text { Jaundice: Juice of leaves is taken internally }{ }^{[24]} \text {. Tonsillitis: } \\
\text { The crushed leaf mixed with water and filtrate is taken }{ }^{[19]} \text {. } \\
\text { Traumatic injury: Root decoction is taken internally }{ }^{[5]} \text {. }\end{array}$ \\
\hline Arhar & $\begin{array}{l}\text { Cajanus cajan (L.) Millsp. } \\
\text { (Fabaceae) }\end{array}$ & Shrub & Leaf, Seed & $\begin{array}{l}\text { Piles: Leaf paste is taken }{ }^{[17]} \text {. Jaundice and pneumonia: Leaf } \\
\text { juice is taken orally }{ }^{[20]} \text {. Bowels: Seed paste is taken externally } \\
\text {. Mother milk secretion: Decoction leaves and seeds are } \\
\text { taken orally }{ }^{[31]} \text {. }\end{array}$ \\
\hline Amra & $\begin{array}{l}\text { Spondias pinnata (L.f.) Kurz. } \\
\text { (Anacardiaceae) }\end{array}$ & Tree & Bark, Root & $\begin{array}{l}\text { Diarrhea, Dysentery and Vomiting: Infusion of the bark is } \\
\text { taken }{ }^{[30]} \text {. Gonorrhea: Decoction of the bark is taken orally }{ }^{[23]} \text {. } \\
\text { Menstruation: Roots are use in regulating menstruation }{ }^{[24]} \text {. }\end{array}$ \\
\hline Aakh & $\begin{array}{l}\text { Saccharum officinarum L. } \\
\text { (Poaceae) }\end{array}$ & Shrub & Stem & Jaundice: Stem juice is taken internally ${ }^{[25]}$. \\
\hline Arjun & $\begin{array}{l}\text { Terminalia arjuna (Roxb.) } \\
\text { Wight \& Arn. } \\
\text { (Combretaceae) }\end{array}$ & Tree & Bark & $\begin{array}{l}\text { Blood pressure \& Heart disease: Extract of stem bark is tak- } \\
\text { en orally }{ }^{[17]} \text {. }\end{array}$ \\
\hline Amm & $\begin{array}{l}\text { Mangifera indica } \mathrm{L} . \\
\text { (Anacardiaceae) }\end{array}$ & Tree & Gum, Leaf & $\begin{array}{l}\text { Fever, Diarrhea and Toothache: Decoction of the leaves is } \\
\text { taken internally }{ }^{[18]} \text {. Skin disease: Gum paste is used externally } \\
{ }^{[22]} \text {. }\end{array}$ \\
\hline Amrul & $\begin{array}{l}\text { Oxalis corniculata } \mathrm{L} . \\
\quad \text { (Oxalidaceae) }\end{array}$ & Herb & Leaf & $\begin{array}{l}\text { Stomach pain: Decoction of leaves mixed with water is orally } \\
\text { taken for the treatment of stomach pain }{ }^{[27]} \text {. Scurvy: Leaves } \\
\text { juice is taken orally to cure scurvy }{ }^{[29]} \text {. }\end{array}$ \\
\hline Amloki & $\begin{array}{c}\text { Phyllanthus emblica L. } \\
\text { (Euphorbiaceae) }\end{array}$ & Tree & $\begin{array}{l}\text { Fruit, Bark, } \\
\text { Leaf }\end{array}$ & $\begin{array}{l}\text { Diabetes: Green fruits and cumbered dry fruits can be used for } \\
\text { treatment of diabetes }{ }^{[23]} \text {. Stomach problem: Fruit powder and } \\
\text { bark juice is taken orally }{ }^{[21]} \text {. Toothache problem: Young fruits } \\
\text { are taken orally. Scurvy: Green fruit is taken internally }{ }^{[10]} \text {. }\end{array}$ \\
\hline
\end{tabular}




\begin{tabular}{|c|c|c|c|c|}
\hline Bangla name & Botanical name and Family name & Habit & Parts Used & Ailments \& Treatment Process \\
\hline Ashok & $\begin{array}{l}\text { Saraca indica } \mathrm{L} . \\
\text { (Caesalpiniaceae) }\end{array}$ & Tree & Bark, Root & $\begin{array}{l}\text { Abortion: Powder of dried bark is taken internally }{ }^{[2]} \text {. Anemia: } \\
\text { Bark extracts mixed with } 1 \text { teaspoon sugar and } 1 \text { glass of milk } \\
\text { is taken orally }{ }^{[27]} \text {. Dysentery: Root extracts mixed with water } \\
\text { is taken }{ }^{[31]} \text {. }\end{array}$ \\
\hline Babla & $\begin{array}{c}\text { Acacia nilotica }(\text { L.) Willd ex } \\
\text { Delile } \\
\text { (Mimosaceae) }\end{array}$ & Tree & $\begin{array}{l}\text { Bark, Leaf, } \\
\text { Bark }\end{array}$ & $\begin{array}{l}\text { Bronchitis: Bark extracts is taken orally }{ }^{[21]} \text {. Dysentery: Pods } \\
\text { are taken internally }{ }^{[11]} \text {. Leucoderma: Leaf decoction is taken } \\
{ }^{[25]} \text {. }\end{array}$ \\
\hline Badarlathi & $\begin{array}{l}\text { Cassia fistula } \mathrm{L} . \\
\text { (Caesalpiniaceae) }\end{array}$ & Tree & $\begin{array}{l}\text { Young Leaf, } \\
\text { Fruit, } \\
\text { Bark }\end{array}$ & $\begin{array}{l}\text { Ringworms: Juice of young leaves is taken orally }{ }^{[24]} \text {. Gout: } \\
\text { Fruits pulp is taken }{ }^{[5]} \text {. Constipation: Leaf decoction is taken } \\
\text { orally }{ }^{[12]} \text {. Diabetes: Decoction of bark mixed with water is } \\
\text { taken }{ }^{[17]} \text {. }\end{array}$ \\
\hline Bhat & $\begin{array}{l}\text { Clerodendrum viscosum Vent. } \\
\text { (Verbenaceae) }\end{array}$ & Shrub & Leaf, Root & $\begin{array}{l}\text { Asthma, tumors and skin diseases: Leaf and root paste is tak- } \\
\text { en externally }{ }^{[20]} \text {. Hair disease: Leaf paste is applied }{ }^{[23]} \text {. }\end{array}$ \\
\hline Basak & $\begin{array}{l}\text { Justicia adhatoda } \mathrm{L} . \\
\text { (Acanthaceae) }\end{array}$ & Shrub & $\begin{array}{l}\text { Whole plant } \\
\text { specially leaf }\end{array}$ & $\begin{array}{l}\text { Cough and Fever: Leaf juice is taken internally }{ }^{[18]} \text {. Piles: The } \\
\text { extract or juice of plant is used in bleeding piles }{ }^{[30]} \text {. }\end{array}$ \\
\hline Bel & $\begin{array}{l}\text { Aegle marmelos (L.) Correa } \\
\text { (Rutaceae) }\end{array}$ & Tree & Fruit, Root & $\begin{array}{l}\text { Stomachache: Unripe wood apple is made pieces and used in } \\
\text { stomachache }{ }^{[4]} \text {. Constipation: Ripe wood apple is made juice } \\
\text { and taken to cure constipation }{ }^{[10]} \text {. Diarrhea: Extract of root is } \\
\text { taken. Heart disease: Root juice is taken internally }{ }^{[23]} \text {. }\end{array}$ \\
\hline Bot & $\begin{array}{l}\text { Ficus benghalensis } \mathrm{L} \text {. } \\
\text { (Moraceae) }\end{array}$ & Tree & $\begin{array}{l}\text { Latex, Root, } \\
\quad \text { Bud }\end{array}$ & $\begin{array}{l}\text { Rheumatic pain: Latex is applied externally }{ }^{[12]} \text {. Vomiting: A } \\
\text { tip of the hanging roots crushed and mixed with water is used } \\
\text { for obstinate vomiting }{ }^{[19]} \text {. Malaria: Grinding, decoction of } \\
\text { young buds; taken orally for malaria }{ }^{[25]} \text {. }\end{array}$ \\
\hline Bohera & $\begin{array}{l}\text { Terminalia bellirica (Gaertn) } \\
\quad \text { Roxb. (Combretaceae) }\end{array}$ & Tree & Green fruit & Cough: Green fruit decoction is taken orally ${ }^{[26]}$. \\
\hline Berela & $\begin{array}{l}\text { Sida cordifolia } \mathrm{L} . \\
\quad \text { (Malvaceae) }\end{array}$ & Herb & Whole plant & $\begin{array}{l}\text { Asthma: } 10 \mathrm{~g} \text { root juice smeared and boiled in } 4-5 \text { cup of } \\
\text { water till it comes to } 2 \text { cup, filtered and the decoction is taken } \\
\text { twice daily for } 1 \text { month }{ }^{[27]} \text {. Bleeding Piles: } 5-6 \text { young leaves } \\
\text { are crushed and applied on the affected area at least } 15-20 \text { days } \\
\text { [29]. Gonorrhea: } 2-3 \text { seedlings are boiled in a } 1 \text { liter of water } \\
\text { till it comes to } 250 \mathrm{ml} \text { then the solution taken orally in early } \\
\text { morning }{ }^{[19]} \text {. Rheumatism: } 2-3 \text { saplings are finely crushed } \\
\text { mixed with little amount of mustered oil, boiled it and then the } \\
\text { solution is taken orally for } 4-5 \text { days }{ }^{[22]} \text {. }\end{array}$ \\
\hline Bherenda & $\begin{array}{l}\text { Ricinus communis } \mathrm{L} \text {. } \\
\quad \text { (Euphorbiaceae) }\end{array}$ & Shrub & Leaf, seed & $\begin{array}{l}\text { Jaundice: Leaf juice is taken orally }{ }^{[30]} \text {. Dysentery: Juice of } \\
\text { tender leaves mixed with sugar is orally taken to cure Dysen- } \\
\text { tery }{ }^{[31]} \text {. Constipation: Seed oil is used internally for the treat- } \\
\text { ment of constipation }{ }^{[23]} \text {. }\end{array}$ \\
\hline Bokul & $\begin{array}{l}\text { Mimusops elengi L. } \\
\quad \text { (Sapotaceae) }\end{array}$ & Tree & Stem-bark & $\begin{array}{l}\text { Swelling: Stem bark decoction is taken }{ }^{[12]} \text {. Asthma: Flowers } \\
\text { smell is used to cure asthma by smoking }{ }^{[19]} \text {. }\end{array}$ \\
\hline Chotra & $\begin{array}{l}\text { Lantana camara } \mathrm{L} . \\
\quad \text { (Verbenaceae) }\end{array}$ & Shrub & Leaf & $\begin{array}{l}\text { Wound: Grind the leaves with turmeric and salt and apply it } \\
\text { twice a week to the wounds }{ }^{[24]} \text {. }\end{array}$ \\
\hline Chirata & $\begin{array}{l}\text { Swertia chirata L. (Gentiana- } \\
\text { ceae) }\end{array}$ & Herb & Whole plant & $\begin{array}{l}\text { Fever: Whole plant juice is taken internally }{ }^{[20]} \text {. Vomiting: } \\
\text { Root juice mixed with honey is taken orally }{ }^{\left[{ }^{[21]}\right.} \text {. }\end{array}$ \\
\hline Chitki & $\begin{array}{l}\text { Phyllanthus reticulatus Poir. } \\
\quad \text { (Euphorbiaceae) }\end{array}$ & Shrub & Leaf, Root & $\begin{array}{l}\text { Diarrhea: } 100 \mathrm{~g} \text { leaves are soaked into } 3 \text { cups of water for } \\
\text { overnight and then administered internally }{ }^{[12]} \text {. Malaria: } 20 \\
\text { gm root is boiled with } 4-5 \text { cups of water till it comes to } 1 \text { cup } \\
\text { and half of the liquid is administered orally in early morning } \\
\text { and other half in the evening for } 4-5 \text { days }{ }^{[22]} \text {. Epilepsy: } 10 \\
\text { gm roots are crushed and soaked in a } 1 \text { liter of water for } 10-12 \\
\text { hours and then the solution taken } 4-5 \text { days }{ }^{[27]} \text {. }\end{array}$ \\
\hline Chatim & $\begin{array}{l}\text { Alstonia scholaris (L.) R. Br. } \\
\text { (Apocynaceae) }\end{array}$ & Tree & $\begin{array}{l}\text { Bark, Gum, } \\
\text { Root }\end{array}$ & $\begin{array}{l}\text { Ulcers: The milky juice of gum is taken orally to cure ulcers } \\
\text {. Cancer: Root extracts is taken orally to cure cancer }{ }^{[28]} \text {. } \\
\text { Rheumatism: Dry bark, salt, and Piper nigrum crushed them } \\
\text { with water and made a paste used for rheumatism }{ }^{[23]} \text {. Gastric } \\
\text { problem: Bark }(50 \mathrm{mg}) \text { is mixed with sufficient salt and ad- } \\
\text { ministered once daily for } 5 \text { days }{ }^{[19]} \text {. }\end{array}$ \\
\hline Dherosh & $\begin{array}{c}\text { Abelmoschus esculentus (L.) } \\
\text { Moench } \\
\text { (Malvaceae) }\end{array}$ & Herb & Fruit & $\begin{array}{l}\text { Stomachic: Water, sugar mixed with fruit juice is taken }{ }^{[25]} \text {. } \\
\text { Female weakness: Young fruits use as a vegetable at lunch } \\
\text { regularly for a month }{ }^{[26]} \text {. Hair fall: Paste of young fruits used } \\
\text { on head regularly } \\
\text { etable regularly }{ }^{[12]} \text {. Constipation: Young fruits use as a veg- }\end{array}$ \\
\hline
\end{tabular}




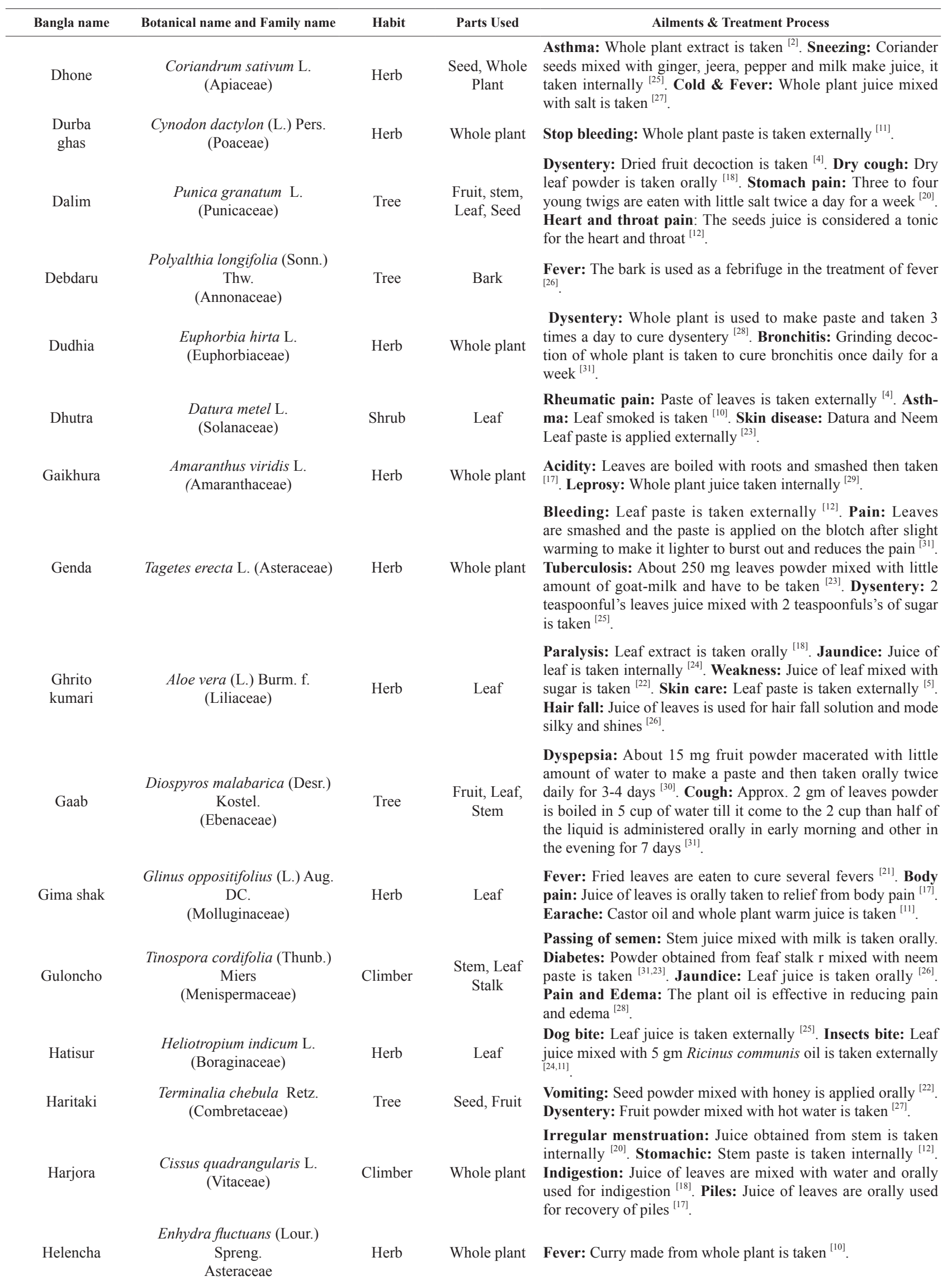




\begin{tabular}{|c|c|c|c|c|}
\hline Bangla name & Botanical name and Family name & Habit & Parts Used & Ailments \& Treatment Process \\
\hline Holud & $\begin{array}{l}\text { Curcuma longa } \mathrm{L} . \\
\text { (Zingiberaceae) }\end{array}$ & Herb & $\begin{array}{l}\text { Rhizome, } \\
\text { Flower }\end{array}$ & $\begin{array}{l}\text { Eczema: Rhizome paste is taken externally }{ }^{[19]} \text {. Dysentery: } \\
\text { Powder made from rhizome mixed with hot rice, mustard oil } \\
\text { and table salt is taken }{ }^{[23]} \text {. Gonorrhea: Paste of flower is taken } \\
{ }^{[18]} \text {. Gastric problem: Fresh rhizome chewing with table salt }{ }^{[21]} \text {. }\end{array}$ \\
\hline $\begin{array}{l}\text { Jagath } \\
\text { madan }\end{array}$ & $\begin{array}{l}\text { Justicia gendarussa } \text { Burm. f. } \\
\text { (Acanthaceae) }\end{array}$ & Shrub & Leaf & $\begin{array}{l}\text { Headache: Leaf is covered with mustard oil then that leaf is } \\
\text { put on the forehead }{ }^{[5,18,31]} \text {. }\end{array}$ \\
\hline Jagdumur & $\begin{array}{l}\text { Ficus racemosa } \mathrm{L} \text {. } \\
\quad \text { (Moraceae) }\end{array}$ & Tree & Fruit & $\begin{array}{l}\text { Dry cough: Curry made from young fruit is taken internally }{ }^{[24]} \text {. } \\
\text { Asthma: Fresh fruit mixed with honey is taken }{ }^{[21]} \text {. Diabetes: } \\
\text { Young dry fruit powder is taken orally }{ }^{[12]} \text {. }\end{array}$ \\
\hline Joba & $\begin{array}{l}\text { Hibiscus rosa-sinensis } \mathrm{L} . \\
\text { (Malvaceae) }\end{array}$ & Shrub & Flower & $\begin{array}{l}\text { Burning wound: Paste of flower is used for burning wound }{ }^{[1]]} \text {. } \\
\text { Irregular menstruations: Paste of flower mixed with water } \\
\text { orally treated twice daily for two weeks }{ }^{[23]} \text {. Cooling and as- } \\
\text { tringent: Powder obtained from flower buds mixed with water } \\
\text { is taken internally }{ }^{[26]} \text {. Hair treatment: Paste of flower used } \\
\text { orally for hair treatment }{ }^{[27]} \text {. }\end{array}$ \\
\hline Jamalkota & $\begin{array}{l}\text { Jatropha curcas L. } \\
\text { (Euphorbiaceae) }\end{array}$ & Shrub & $\begin{array}{l}\text { Leaf, Seeds, } \\
\text { Gums, Stems, }\end{array}$ & $\begin{array}{l}\text { Fever: Juice made from Jamalgota leaf, lemon leaf and ata leaf } \\
\text { mixed with hot water is taken }{ }^{[25]} \text {. Worms: Paste made from } \\
\text { seeds is taken internally }{ }^{[28]} \text {. Cancer: Decoctions of leaves are } \\
\text { used for anti-cancer }{ }^{[29]} \text {. Constipation: Gum mixed with liquid } \\
\text { food and orally treated }{ }^{[22]} \text {. }\end{array}$ \\
\hline Jam & $\begin{array}{l}\text { Syzygium cumini (L.) Skeels. } \\
\text { (Myrtaceae) }\end{array}$ & Tree & $\begin{array}{l}\text { Bark, Seed, } \\
\text { Fruit }\end{array}$ & $\begin{array}{l}\text { Asthma: Bark decoction is taken internally }{ }^{[24]} \text {. Diabetes: } \\
\text { Seed paste is taken with sugar or a pinch of salt, fruits extracts } \\
\text { taken daily against diabetes }{ }^{[31,23]} \text {. }\end{array}$ \\
\hline Kalomegh & $\begin{array}{l}\text { Andrographis paniculata } \\
\text { (Burm.f.) Nees. } \\
\text { (Acanthaceae) }\end{array}$ & Herb & Leaf & $\begin{array}{l}\text { Fever, headache, diarrhea, and cholera: Juice obtained from } \\
\text { leaves is taken internally }{ }^{[2]]} \text {. Lung infections: Decoction of } \\
\text { leaf is taken orally }{ }^{[21]} \text {. Leprosy: Paste of leaf is taken external- } \\
\text { ly }{ }^{[25]} \text {. }\end{array}$ \\
\hline Kamranga & $\begin{array}{l}\text { Averrhoa carambola } \mathrm{L} . \\
\quad \text { (Oxalidaceae) }\end{array}$ & Tree & Fruit, Leaf & $\begin{array}{l}\text { Piles: After slicing the star fruit it has to be boiled in open } \\
\text { sunlight for } 1 \text { week and to make dry powder out of it. Then } 1.5 \\
\text { gm of that powder of star fruit has to be taken with one glass of } \\
\text { water twice every day }{ }^{[17]} \text {. Fever: } 2 \mathrm{gm} \text { dry powder of star fruit } \\
\text { leaves has to be taken with } 1.2 \text { cup of water every day morning } \\
\text { and evening for } 3 / 4 \text { days }{ }^{[20]} \text {. Dysentery: In an intense stage of } \\
\text { these ailments } 1 \text { teaspoonful of extract or juice of ripens star } \\
\text { fruit has to be taken to improve the situation }{ }^{\left[{ }^{111}\right]} \text {. Liver pain: } 3-4 \\
\text { teaspoonful of ripen star fruit juice to be taken with water to } \\
\text { improve this condition }{ }^{[21]} \text {. }\end{array}$ \\
\hline Karamcha & $\begin{array}{l}\text { Carissa carandas L. } \\
\text { (Apocynaceae) }\end{array}$ & Shrub & $\begin{array}{l}\text { Fruit, Root, } \\
\text { bark }\end{array}$ & $\begin{array}{l}\left.\text { Diabetes: Root bark decoction is taken orally }{ }^{[22}\right] \text {. Wound: De- } \\
\text { coction of root bark is orally taken internally }{ }^{[12]} \text {. }\end{array}$ \\
\hline Katanotey & $\begin{array}{l}\text { Amaranthus spinosus L. } \\
\text { (Amaranthaceae) }\end{array}$ & Herb & Whole plant & $\begin{array}{l}\text { Toothache: Whole plant decoction is taken }{ }^{[23]} \text {. Dysentery: } \\
\text { Leaf juice is taken internally }{ }^{[10]} \text {. Wounds: Leaf paste is taken } \\
\text { externally }{ }^{[31]} \text {. }\end{array}$ \\
\hline Kathal & $\begin{array}{l}\text { Artocarpus heterophyllus Lam. } \\
\text { (Moraceae) }\end{array}$ & Tree & Root, Leaf & $\begin{array}{l}\text { Diarrhea: Decoction of roots is used internally in diarrhea }{ }^{[2]} \text {. } \\
\text { Skin disease: Yong leaves paste used regularly on infected } \\
\text { skin }{ }^{[5]} \text {. }\end{array}$ \\
\hline Kalokeshi & $\begin{array}{l}\text { Eclipta alba }(\text { L.) Hassk. } \\
\text { (Asteraceae) }\end{array}$ & Herb & Whole plant & $\begin{array}{l}\text { Diarrhea: Leaf juice mixed with sugar or honey is taken }{ }^{[10]} \text {. } \\
\text { Constipation: Pounded leaf mixed with cold water is taken }{ }^{[11]} \text {. } \\
\text { Hair treatment: Leaf paste is applied externally }{ }^{[5]} \text {. }\end{array}$ \\
\hline Kochu & $\begin{array}{l}\text { Colocasia esculenta }(\mathrm{L} .) \\
\text { Schott. } \\
\text { (Araceae) }\end{array}$ & Herb & Leaf, Petiole & $\begin{array}{l}\text { Stop bleeding: Leaf juice taken externally }{ }^{[17]} \text {. Tumors } \& \\
\text { Cancer: Leaf juice is taken internally }{ }^{[30]} \text {. }\end{array}$ \\
\hline Korobi & $\begin{array}{l}\text { Nerium oleander L. } \\
\text { (Apocynaceae) }\end{array}$ & Tree & Leaf, Root bark & $\begin{array}{l}\text { Ulcer \& Joints pain: Root bark paste is taken externally }{ }^{[25]} \text {. } \\
\text { Insect bite \& Swellings: Young leaf decoction is taken exter- } \\
\text { nally }{ }^{[18]} \text {. }\end{array}$ \\
\hline Kola & $\begin{array}{l}\text { Musa sapientum } \mathrm{L} . \\
\quad \text { (Musaceae) }\end{array}$ & & Stem, Bark & $\begin{array}{l}\text { Stop bleeding: Stem juice is taken }{ }^{[11]} \text {. Snake bite: Bark juice } \\
\text { is taken externally }{ }^{[18]} \text {. }\end{array}$ \\
\hline Kalijeeri & $\begin{array}{l}\text { Nigella sativa } \mathrm{L} \text {. } \\
\text { (Ranunculaceae) }\end{array}$ & Herb & Seed & $\begin{array}{l}\text { Blood pressure: Seed oil is taken orally }{ }^{[20]} \text {. Asthma: Black } \\
\text { seed is taken internally }{ }^{[31]} \text {. }\end{array}$ \\
\hline Korolla & $\begin{array}{l}\text { Momordica charantia } \mathrm{L} . \\
\quad \text { (Cucurbitaceae) }\end{array}$ & Climber & Whole plant & $\begin{array}{l}\text { Colic and fever: Whole plant juice is taken }{ }^{[2]} \text {. Diabetes: Juice } \\
\text { of the whole plant orally taken to treated diabetes. The leaves } \\
\text { juice is taken orally daily for diabetes }{ }^{[12]} \text {. Headache: Root } \\
\text { paste is used in headache }{ }^{[2]} \text {. Stomachic: Cooked fruits used as } \\
\text { stomachic }{ }^{[30]} \text {. }\end{array}$ \\
\hline
\end{tabular}




\begin{tabular}{|c|c|c|c|c|}
\hline Bangla name & Botanical name and Family name & Habit & Parts Used & Ailments \& Treatment Process \\
\hline Kolmi shak & $\begin{array}{l}\text { Ipomoea aquatica Forssk. } \\
\text { (Convolvulaceae) }\end{array}$ & Climber & Whole plant & $\begin{array}{l}\text { Jaundice and Bronchitis: Dry leaf powder mixed with cold } \\
\text { water is taken orally }{ }^{[24]} \text {. Fever, Anthelmintic, Carminative, } \\
\text { Leprosy, and Liver complaints: Cooked vegetables are taken } \\
\text { orally }{ }^{[31]} \text {. }\end{array}$ \\
\hline Kotbel & $\begin{array}{l}\text { Feronia acidissima } \mathrm{L} . \\
\quad \text { (Rutaceae) }\end{array}$ & Tree & $\begin{array}{l}\text { Stem, Leaf, } \\
\text { Fruit }\end{array}$ & $\begin{array}{l}\text { Piles: Paste prepared from stem bark is applied externally }{ }^{[26]} \text {. } \\
\text { Vomiting: Leaves juice is orally taken to control vomiting }{ }^{[28]} \text {. } \\
\text { Heart disease: Fruits juice is orally taken to help heart disease } \\
\text { and digestion }{ }^{[18]} \text {. }\end{array}$ \\
\hline Khoksha dumur & $\begin{array}{l}\text { Ficus hispida } \text { L.f. } \\
\quad \text { (Moraceae) }\end{array}$ & Tree & Fruit & $\begin{array}{l}\text { Diabetes: Juice of fruit mixed with water is taken orally }{ }^{[22]} \text {. } \\
\text { Jaundice: Fruit decoction is applied }{ }^{[26]} \text {. }\end{array}$ \\
\hline Lajjaboti & $\begin{array}{l}\text { Mimosa pudica L. } \\
\text { (Mimosaceae) }\end{array}$ & Herb & Root, Leaf & $\begin{array}{l}\text { Diarrhea: Root paste is taken }{ }^{[4]} \text {. Piles: Root juice is taken ex- } \\
\text { ternally }{ }^{[18]} \text {. Snake bites: Root juice mixed with raw cow milk } \\
\text { is taken internally }{ }^{[20]} \text {. Muscular pain: Decoction of leaf mixed } \\
\text { with water is taken }{ }^{[21]} \text {. }\end{array}$ \\
\hline Lebu & $\begin{array}{c}\text { Citrus aurantifolia (Christm.) } \\
\text { Swingle } \\
\text { (Rutaceae) }\end{array}$ & Shrub & Fruit & $\begin{array}{l}\text { Catarrhal fever: Fruit juice mixed with honey is taken orally } \\
\text { [24]. Apetite: Has to eat by making lemonade or may be taken } \\
\text { with rice }{ }^{[21]} \text {. Nausea: Juice of fruits is taken internally }{ }^{[25]} \text {. } \\
\text { Stomachache: Fruit juice mixed with water and taken it every } \\
\text { morning in empty stomachache }{ }^{[23]} \text {. }\end{array}$ \\
\hline Luchipata & $\begin{array}{l}\text { Peperomia pellucida Kunth. } \\
\quad \text { (Piperaceae) }\end{array}$ & Herb & Leaf & $\begin{array}{l}\text { Headache: Crushed leaf is applied externally }{ }^{[12]} \text {. Abdominal } \\
\text { pains and Fever: Leaf juice is taken }{ }^{[26]} \text {. }\end{array}$ \\
\hline Litchu & $\begin{array}{l}\text { Litchi chinensis Sonn. } \\
\text { (Sapindaceae) }\end{array}$ & Tree & Fruit & $\begin{array}{l}\text { Heart, brain and liver: Fruits are tonic to the heart, brain and } \\
\text { liver }^{[28]} \text {. }\end{array}$ \\
\hline Mehedi & $\begin{array}{l}\text { Lawsonia inermis L. } \\
\quad \text { (Lythraceae) }\end{array}$ & Shrub & Leaf & $\begin{array}{l}\text { Skin disease: Leaf paste is taken externally }{ }^{[20]} \text {. Hair treat- } \\
\text { ment: Leaves pastes are valuable external used in hair fall } \\
\text { solution and make hair silky and shine }{ }^{[23]} \text {. }\end{array}$ \\
\hline Madar & $\begin{array}{l}\text { Erythrina orientalis Murr. } \\
\text { (Fabaceae) }\end{array}$ & Tree & Leaf, Root & $\begin{array}{l}\text { Joints pain: Paste of leaves is applied externally to relief pain } \\
\text { of the joints }{ }^{[12]} \text {. Earache: Leaves juice is poured into the ear } \\
\text { to relief earache }{ }^{[21]} \text {. Toothache: Leaves juice is used to relief } \\
\text { toothache }{ }^{[18]} \text {. Nematode: Extract of roots is taken once daily } \\
\text { as much as patient can to control }{ }^{[29]} \text {. }\end{array}$ \\
\hline Mankochu & $\begin{array}{c}\text { Alocasia macrorrhizos (L.) G. } \\
\text { Don. } \\
\text { (Araceae) }\end{array}$ & Herb & Fruit, Petiole & $\begin{array}{l}\text { Snakebite: Paste of petiole used in affected area treated for } \\
\text { snake bite }{ }^{[5]} \text {. Fever: Fried of fruit is taken to cure several fe- } \\
\text { vers }{ }^{[17]} \text {. }\end{array}$ \\
\hline Mistialo & $\begin{array}{l}\text { Ipomoea batatas (L.) Lam. } \\
\quad \text { (Convolvulaceae) }\end{array}$ & Climber & Tuber, Leaf & $\begin{array}{l}\text { Edema: At least10-12 leaves are paste and used in the affected } \\
\text { area for at least } 1 \text { month }{ }^{[25]} \text {. Dysentery: Sweet potato grained } \\
\text { with appropriate amount of water and } 1 \text { teaspoonful filtered ex- } \\
\text { tract of it has to be taken } 15-20 \text { minutes alternately to treat the } \\
\text { disease }{ }^{[28]} \text {. Skin disease: Tuber paste is taken externally }{ }^{[29]} \text {. }\end{array}$ \\
\hline Mohavringaraj & $\begin{array}{l}\text { Wedelia chinensis (Osbeck) } \\
\text { Merr. } \\
\text { (Asteraceae) }\end{array}$ & Herb & Leaf & $\begin{array}{l}\text { Alopecia: Leaf paste is taken externally }{ }^{[5]} \text {. Stop vomiting: } \\
\text { Leaf juice mixed with salt is taken orally }{ }^{[2]]} \text {. }\end{array}$ \\
\hline Morich & $\begin{array}{l}\text { Capsicum frutescens } \mathrm{L} \text {. } \\
\quad \text { (Solanaceae) }\end{array}$ & Herb & Leaf, Fruit & $\begin{array}{l}\text { Night blindness: Juice of leaves is used to cure night blind- } \\
\text { ness }{ }^{[17]} \text {. Headache: Leaves are used in headache on forehead } \\
{ }^{[28]} \text { Blood dysentery: Chili powder mixed with water and fried } \\
\text { with hot rice is taken internally }{ }^{[26]} \text {. Mouth disease: Young fruit } \\
\text { paste is taken }{ }^{[25]} \text {. }\end{array}$ \\
\hline Muktajhuri & $\begin{array}{l}\text { Acalypha indica L. } \\
\text { (Euphorbiaceae) }\end{array}$ & Herb & Leaf & $\begin{array}{l}\text { Ringworm: Leaf juice is taken orally }{ }^{[24]} \text {. Snake bite: Leaf } \\
\text { paste is applied externally }{ }^{[20]} \text {. }\end{array}$ \\
\hline Mutha & $\begin{array}{l}\text { Cyperus rotundus } \mathrm{L} . \\
\text { (Cyperaceae) }\end{array}$ & Herb & Tuber, Root & $\begin{array}{l}\text { Fever: Fresh root are crushed and boiled in } 5 \text { cup of water re- } \\
\text { duced to } 3 \text { cup then filtered it and the decoction has to be taken } \\
\text { twice per day }{ }^{[31]} \text {. Diarrhea: About } 5 \text { gm of crushed root are } \\
\text { soaked overnight in } 3 \text { cup of water and taken twice daily for } \\
3-5 \text { days }{ }^{[26]} \text {. Wounds \& Sores: Macerated root paste is taken } \\
\text { externally }{ }^{[22]} \text {. }\end{array}$ \\
\hline Nayantara & $\begin{array}{l}\text { Catharanthus roseus (L.) G. } \\
\text { Don. } \\
\text { (Apocynaceae) }\end{array}$ & Herb & Whole plant & $\begin{array}{l}\text { Leukemia: Whole plant is plucked and made juice which helps } \\
\text { in leukemia }{ }^{[2,5,26]} \text {. }\end{array}$ \\
\hline Neem & $\begin{array}{l}\text { Azadirachta indica A. Juss. } \\
\text { (Meliaceae) }\end{array}$ & Tree & Leaf & $\begin{array}{l}\text { Chicken pox: Leaf paste mixed warm water is taken externally } \\
{[17] \text {. Jaundice: Juice of leaf is taken }{ }^{[28]} \text {. Pyorrhea: Leaf decoc- }} \\
\text { tion is taken }{ }^{[11]} \text {. Skin disease: Paste of leaf is taken externally } \\
{[29] \text {. }}\end{array}$ \\
\hline Nishinda & $\begin{array}{l}\text { Vitex negundo L. } \\
\text { (Verbenaceae) }\end{array}$ & Shrub & Leaf & $\begin{array}{l}\text { Headache: Tonic obtained from leaf is taken }{ }^{[18]} \text {. Catarrhal } \\
\text { fever: Leaf decoction mixed with long pepper is taken }{ }^{[12]} \text {. }\end{array}$ \\
\hline
\end{tabular}




\begin{tabular}{|c|c|c|c|c|}
\hline Bangla name & Botanical name and Family name & Habit & Parts Used & Ailments \& Treatment Process \\
\hline Oporajita & $\begin{array}{l}\text { Clitoria ternetea } \mathrm{L} . \\
\quad \text { (Fabaceae) }\end{array}$ & Climber & Root, Leaf & $\begin{array}{l}\text { Throat pain \& Swelling: Leaf paste is taken externally }{ }^{[23]} \text {. } \\
\text { Tuberculosis: Root decoction is taken orally }{ }^{[27]} \text {. Headache: } \\
\text { Leaf paste is taken externally }{ }^{[31]} \text {. }\end{array}$ \\
\hline Piaj & $\begin{array}{l}\text { Allium cepa } \mathrm{L} \text {. } \\
\text { (Liliaceae) }\end{array}$ & Herb & Bulb & $\begin{array}{l}\text { Cold \& Cough: Warm bulb juice along with Brassica napus } \\
\text { oil is taken by massage of the whole body to cure common } \\
\text { cold, cough }{ }^{[28]} \text {. Headache: Warm blub juice along with Brias- } \\
\text { sica napus oil is applied on head to cure headache }{ }^{[30]} \text {. Snake } \\
\text { bite: Macerated bulb juice is applied on the affected area for } \\
\text { snake bite }{ }^{[10]} \text {. }\end{array}$ \\
\hline Palash & $\begin{array}{l}\text { Butea monosperma }(\text { Lam.) } \\
\text { Taub. } \\
\text { (Fabaceae) }\end{array}$ & Tree & $\begin{array}{l}\text { Flower, Leaf, } \\
\text { Seed }\end{array}$ & $\begin{array}{l}\text { Diarrhea: Flower infusion is given }{ }^{[12]} \text {. Urinary disease: } \\
\text { Flower juice mined with milk is orally taken to cure urinary } \\
\text { complaints }{ }^{[25]} \text {. Body toxin: Flower is used to remove body } \\
\text { toxins }{ }^{[23]} \text {. }\end{array}$ \\
\hline Pakur & $\begin{array}{l}\text { Ficus religiosa } \mathrm{L} \text {. } \\
\quad \text { (Moraceae) }\end{array}$ & Tree & Fruit & $\begin{array}{l}\text { Asthma: The dried fruit, pulverized and taken in water for fort- } \\
\text { night removes asthma }{ }^{[2]} \text {. Dry cough: Fruits extracts or cooked } \\
\text { vegetable are taken orally for dry cough }{ }^{[11]} \text {. }\end{array}$ \\
\hline Pathorkuchi & $\begin{array}{l}\text { Kalanchoe pinnata }(\mathrm{Lam} .) \\
\text { Pers. (Crassulaceae) }\end{array}$ & Herb & Whole plant & $\begin{array}{l}\text { Wounds, boils and insect bite: Leaf paste is taken externally } \\
\text { [23]. }\end{array}$ \\
\hline Pepulte & $\begin{array}{c}\text { Litsea glutinosa } \text { (Lour.) C.B. } \\
\text { Rob. } \\
\text { (Lauraceae) }\end{array}$ & Tree & Leaf, Bark & Diarrhea and dysentery: Bark juice is taken internally ${ }^{[31]}$. \\
\hline Punarnava & $\begin{array}{l}\text { Boerhaavia diffusa } \mathrm{L} \text {. } \\
\text { (Nyctaginaceae) }\end{array}$ & Herb & Root, leaf & $\begin{array}{l}\text { Diuretic: The root paste mixed with water is orally applied as } \\
\text { a diuretic twice daily }{ }^{[24]} \text {. Asthma: Decoctions of the roots and } \\
\text { leaves are taken in moderate doses to cure asthma }{ }^{[27]} \text {. }\end{array}$ \\
\hline Puishak & $\begin{array}{l}\text { Basella alba } \mathrm{L} . \\
\text { (Basellaceae) }\end{array}$ & Climber & Leaf, Root & $\begin{array}{l}\text { Constipation: Leaf juice is taken orally }{ }^{[29]} \text {. Toothache: Root } \\
\text { is applied internally }{ }^{[24]} \text {. Burning sensation: Leaves paste is } \\
\text { used for burning sensation }{ }^{[12]} \text {. }\end{array}$ \\
\hline Pan & $\begin{array}{l}\text { Piper betel L. } \\
\text { (Piperaceae) }\end{array}$ & Climber & Leaf & $\begin{array}{l}\text { Phlegm: Leaves serves as a natural expectorant and aids in } \\
\text { easy removal of phlegm }{ }^{[30]} \text {. Killing lice and cough: Leaf juice } \\
\text { helps in killing lice and in reducing cough }{ }^{[31]} \text {. }\end{array}$ \\
\hline Pipul & $\begin{array}{l}\text { Piper longum L. } \\
\text { (Piperaceae) }\end{array}$ & Climber & Leaf, Bark & $\begin{array}{l}\text { Weakness: Bark extract mixed with water is used in the mari- } \\
\text { nade for body weakness }{ }^{[24]} \text {. Dyspepsia: } 250 \mathrm{mg} \text { (leaf) dust of } \\
\text { this plant has to be taken with one glass of water for } 1 \text { week }^{[23]} \text {. } \\
\text { Asthma: } 250 \mathrm{mg} \text { leaves dust of this plant mixed with water is } \\
\text { taken internally }{ }^{[25]} \text {. Rheumatism: } 250 \mathrm{mg} \text { leaves powder of } \\
\text { this plant mixed with } 1 \text { teaspoonful of ginger extract has to be } \\
\text { taken } 2 \text { times daily }{ }^{[28]} \text {. }\end{array}$ \\
\hline Piyara & $\begin{array}{l}\text { Psidium guajava } \mathrm{L} . \\
\quad \text { (Myrtaceae) }\end{array}$ & Tree & Leaf, Bark & $\begin{array}{l}\text { Diarrhea: Leaf and stem bark decoction is taken internally }{ }^{[30]} \text {. } \\
\text { Mouth wash: Young leaf is taken }{ }^{[27]} \text {. Dysentery: Paste of root } \\
\text { mixed with water is taken orally }{ }^{[17]} \text {. }\end{array}$ \\
\hline Rasun & $\begin{array}{l}\text { Allium sativum L. } \\
\text { (Liliaceae) }\end{array}$ & Herb & Bulb & $\begin{array}{l}\text { Cough and fever: Bulb extract is taken orally }{ }^{[29]} \text {. Eczema and } \\
\text { scabies: Bulb paste is taken externally }{ }^{[31]} \text {. High blood pres- } \\
\text { sure: Garlic bulb mixed with hot rice is taken internally }{ }^{[19]} \text {. }\end{array}$ \\
\hline Roktodron & $\begin{array}{l}\text { Leonurus sibiricus } \mathrm{L} . \\
\quad \text { (Lamiaceae) }\end{array}$ & Herb & Whole plant & $\begin{array}{l}\text { Menstrual disease and Uterus contraction: Dried whole } \\
\text { plant is taken internally }{ }^{[18]} \text {. Febrifuge: Decoction of root and } \\
\text { leaves are taken orally }{ }^{[12]} \text {. }\end{array}$ \\
\hline Setodron & $\begin{array}{l}\text { Leucas aspera } \mathrm{L} . \\
\quad \text { (Lamiaceae) }\end{array}$ & Herb & Leaf, Root & $\begin{array}{l}\text { Snake-bite: Macerated leaf is administered orally }{ }^{[18]} \text {. Rheu- } \\
\text { matism: Leaf juice is taken internally }{ }^{[12]} \text {. Stomach pain: Leaf } \\
\text { extract is taken }{ }^{[26]} \text {. Psoriasis and skin disease: Leaves pastes } \\
\text { are orally used to care psoriasis and other skin disease }{ }^{[29]} \text {. }\end{array}$ \\
\hline Shim & $\begin{array}{l}\text { Lablab purpureus (L.) Sweet. } \\
\text { (Fabaceae) }\end{array}$ & Climber & Leaf & $\begin{array}{l}\text { Skin disease: Leaf paste is taken externally }{ }^{[21]} \text {. Burning sen- } \\
\text { sation: Leaf paste is used internally }{ }^{[27]} \text {. }\end{array}$ \\
\hline Sisso & $\begin{array}{l}\text { Dalbergia sissoo Roxb. } \\
\quad \text { (Fabaceae) }\end{array}$ & Tree & Leaf, Bark & $\begin{array}{l}\text { Hemorrhage: Dried bank is used as a local astringent and } \\
\text { haemostatic in various forms of hemorrhage }{ }^{[23]} \text {. Gonorrhea: } \\
\text { Decoction of leaves is taken orally to acute stage of gonorrhea } \\
{ }^{[19]} \text {. Dysentery: Leaf decoction is taken internally }{ }^{[17]} \text {. }\end{array}$ \\
\hline Shialkata & $\begin{array}{l}\text { Argemone mexicana } \mathrm{L} . \\
\text { (Papaveraceae) }\end{array}$ & Herb & Root, Latex & $\begin{array}{l}\text { Skin cracks: Latex and root paste is taken externally }{ }^{[21]} \text {. Jaun- } \\
\text { dice: Latex is taken internally }{ }^{[11]} \text {. Tumors and cancer: Latex } \\
\text { is used for tumors, cancer }{ }^{[2]} \text {. Malarial fever: Shiailkata root } \\
\text { mixed with betel leaf juice is taken orally }{ }^{[20]} \text {. }\end{array}$ \\
\hline Shimul & $\begin{array}{l}\text { Bombax ceiba } \mathrm{L} \text {. } \\
\text { (Bombacaceae) }\end{array}$ & Tree & Gum & $\begin{array}{l}\text { Burning sensation: Paste of gum is taken externally }{ }^{[18]} \text {. Sex- } \\
\text { ual weakness: Young root extracts mixed with boiled water is } \\
\text { taken }{ }^{[5]} \text {. Rheumatism: Root bark decoction is taken internally } \\
{\left[{ }^{10]} \text {. }\right.}\end{array}$ \\
\hline
\end{tabular}




\begin{tabular}{|c|c|c|c|c|}
\hline Bangla name & Botanical name and Family name & Habit & Parts Used & Ailments \& Treatment Process \\
\hline Sorisha & $\begin{array}{l}\text { Brassica napus L. } \\
\text { (Brassicaceae) }\end{array}$ & Herb & Seed & $\begin{array}{l}\text { Hair treatment: Seed oil is boiled slightly and externally used } \\
\text { in hair. It makes hair strong and shines }{ }^{[27]} \text {. Sleep: Seed oil } \\
\text { used on head to for good sleep }{ }^{[23]} \text {. Skin cracks: To avoid skin } \\
\text { cracks seed oil applied on skin }{ }^{[19]} \text {. Gout: Plaster of mustard is } \\
\text { used in gout } t^{[12]} \text {. Cough and Neuralgic: Warm seed oil is taken } \\
\text { externally }{ }^{[29]} \text {. }\end{array}$ \\
\hline Supari & $\begin{array}{l}\text { Areca catechu } \mathrm{L} \text {. } \\
\quad \text { (Arecaceae) }\end{array}$ & Tree & Seed, Root & $\begin{array}{l}\text { Teaniasis: Crushed of fresh seeds is taken orally }{ }^{[25,29]} \text {. Blood } \\
\text { Dysentery: } 4 \text { gm fresh seed are crushed and has to be boiled } \\
\text { in } 3 \text { cup of water until it comes to } 1 \text { cup then filtered it and the } \\
\text { decoction taken twice a day as a remedy against blood dysen- } \\
\text { tery }{ }^{[31,12]} \text {. Toothache: Equal amount of root powder and dry } \\
\text { nut powder are to fry in the pots and make ash out of it. Then } \\
\text { the ash may be used for brushing the teeth as a remedy against } \\
\text { toothache }{ }^{[29]} \text {. Sore: Fruit has to be dried in open sunlight and } \\
\text { to make dry powder out of it. Then the powder applied on the } \\
\text { affected area }{ }^{[23]} \text {. }\end{array}$ \\
\hline Sarpogandha & $\begin{array}{l}\text { Rauvolfia serpentina }(\mathrm{L} .) \text { Benth } \\
\quad \text { ex Kurz.(Apocynaceae) }\end{array}$ & Herb & Root & $\begin{array}{l}\text { Blood pressure and Dysentery: Extract obtained from root is } \\
\text { taken internally }{ }^{[28]} \text {. }\end{array}$ \\
\hline Shapla & $\begin{array}{l}\text { Nymphaea nouchali Burm. f. } \\
\text { (Nymphaeaceae) }\end{array}$ & Herb & Rhizom, Leaf & $\begin{array}{l}\text { Dysentery: Dried rhizome powder mixed with water as used } \\
\text { for dysentery }{ }^{[17]} \text {. Burning spot: Paste of leaves is used to re- } \\
\text { move burning spot }{ }^{[25]} \text {. }\end{array}$ \\
\hline Sajna & $\begin{array}{l}\text { Moringa oliefera Lam. } \\
\quad \text { (Moringaceae) }\end{array}$ & Tree & $\begin{array}{l}\text { Leaf, Root, } \\
\text { Fruits, Seed. }\end{array}$ & $\begin{array}{l}\text { Blood pressure: Whole leaves cooked and eaten in high blood } \\
\text { pressure }{ }^{[23]} \text {. Abortion: Paste obtained from root bark is taken } \\
\text { orally }{ }^{[11]} \text {. Fever and abdomen pain: Extract obtained from } \\
\text { root is taken orally }{ }^{[20]} \text {. Rheumatism: Oil obtained from seed is } \\
\text { taken }{ }^{[28]} \text {. Diabetes: Leaves are dried on heat and if taken with } \\
\text { rice regularly, help in controlling diabetes }{ }^{[12]} \text {. Cold \& Cough: } \\
\text { Leaf extract is taken internally }{ }^{\left[{ }^{[2]} \text {. }\right.}\end{array}$ \\
\hline Sheuli & $\begin{array}{l}\text { Nyctanthes arbor-tristis } \mathrm{L} \text {. } \\
\text { (Oleaceae) }\end{array}$ & Tree & $\begin{array}{l}\text { Bark, Leaf, } \\
\text { Roots }\end{array}$ & $\begin{array}{l}\text { Chronic fever: Leaves juice mixed with honey is orally in } \\
\text { chronic fever }{ }^{[11]} \text {. Round and thread-worms: Root juice is } \\
\text { taken orally }{ }^{[5]} \text {. Rheumatic fever: Juice obtaine from bark is } \\
\text { taken orally }{ }^{[17]} \text {. Bronchitis: Leaf decoction is taken internally } \\
\text { [23]. }\end{array}$ \\
\hline Tulsi & $\begin{array}{l}\text { Ocimum sanctum } \mathrm{L} . \\
\quad \text { (Lamiaceae) }\end{array}$ & Herb & Leaf & $\begin{array}{l}\text { Coughs, colds, fever and bronchitis: The leaves juice is taken } \\
\text { internally }{ }^{[23]} \text {. }\end{array}$ \\
\hline Thankuni & $\begin{array}{l}\text { Centella asiatica }(\mathrm{L} .) \text { Urban. } \\
\text { (Apiaceae) }\end{array}$ & Herb & Whole plant & $\begin{array}{l}\text { Loose motion, Dysentery and Stomach pain: Whole plant } \\
\text { paste is taken internally }{ }^{[17]} \text {. Tuberculosis: Whole plant juice is } \\
\text { taken internally }{ }^{[20]} \text {. }\end{array}$ \\
\hline Tejpata & $\begin{array}{l}\text { Cinnamomum tamala (Buch.- } \\
\text { Ham.) Nees \& Eberm. } \\
\text { (Lauraceae) }\end{array}$ & Tree & Leaf, Bark & $\begin{array}{l}\text { Diabetes: Leaf juice is taken internally }{ }^{[19]} \text {. Bronchitis: Oil ob- } \\
\text { tained from leaf mixed with honey is taken internally }{ }^{[10]} \text {. Cold } \\
\text { \& Cough: Dry leafs beady is use to smocking for few times to } \\
\text { cure cough caused cold }^{[17]} \text {. }\end{array}$ \\
\hline Telakucha & $\begin{array}{l}\text { Coccinia grandis }(\mathrm{L} .) \text { Voigt } \\
\text { (Cucurbitaceae) }\end{array}$ & Climber & Leaf & $\begin{array}{l}\text { Hypertension: Juice obtained from leaf is taken internally }{ }^{[12]} \text {. } \\
\text { Fever and Vomiting: Juice obtained from crushed leaf juice } \\
\text { mixed with water is taken orally }{ }^{[26]} \text {. }\end{array}$ \\
\hline Tetul & $\begin{array}{l}\text { Tamarindus indica } \mathrm{L} . \\
\quad \text { (Fabaceae) }\end{array}$ & Tree & $\begin{array}{l}\text { Fruit, Seed, } \\
\text { Leaf }\end{array}$ & $\begin{array}{l}\text { Fever: Ripe fruit pulp is taken internally }{ }^{[4]} \text {. Gastritis: } 200 \text { gm } \\
\text { dry seed powder is boiled with } 3 \text { cups of water till to reduce } 2 \\
\text { cups and then taken orally twice daily for } 7-9 \text { days }{ }^{[25]} \text {. Blood } \\
\text { Dysentery: Leaf juice is taken orally }{ }^{[21]} \text {. Mouth disease: } \\
\text { Boiled decoction of stem and bark is administered thrice for } 5 \\
\text { days to prevent mouth disease }{ }^{[28]} \text {. }\end{array}$ \\
\hline Titbegun & $\begin{array}{l}\text { Solanum nigrum L. } \\
\quad \text { (Solanaceae) }\end{array}$ & Herb & Leaf, Fruit & $\begin{array}{l}\text { Dropsy: Leaf decoction is taken internally }{ }^{[12]} \text {. Ringworm: } \\
\text { Green fruit paste is taken orally }{ }^{[19]} \text {. }\end{array}$ \\
\hline Tridhara & $\begin{array}{l}\text { Tridax procumbens L. (Astera- } \\
\text { ceae) }\end{array}$ & Herb & Leaf & $\begin{array}{l}\text { Dysentery and Diarrhea: Juice obtained from leaf is taken }{ }^{[21]} \text {. } \\
\text { Bronchitis: Juice obtained from crushed leaf mixed with water } \\
\text { is applied internally }{ }^{[24]} \text {. Bleeding: Paste of crushed leaf is tak- } \\
\text { en externally }{ }^{[29]} \text {. }\end{array}$ \\
\hline $\begin{array}{l}\text { Ulot } \\
\text { kambal }\end{array}$ & $\begin{array}{l}\text { Abroma augusta L.f. } \\
\quad \text { (Sterculiaceae) }\end{array}$ & Shrub & Petiol, Seed & $\begin{array}{l}\text { Weakness: Juice obtained from petiole mixed with sugar is } \\
\text { taken orally }{ }^{[26]} \text {. Stomach pain: Paste of seed mixed with water } \\
\text { is applied internally }{ }^{[31]} \text {. }\end{array}$ \\
\hline
\end{tabular}




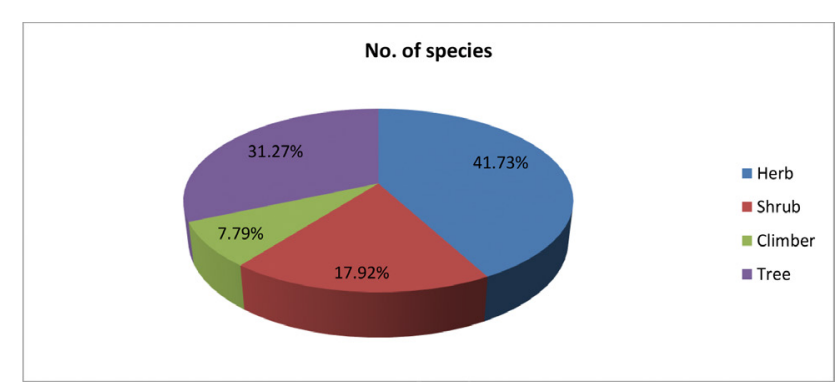

Figure 1. Investigated plant habit in the study area

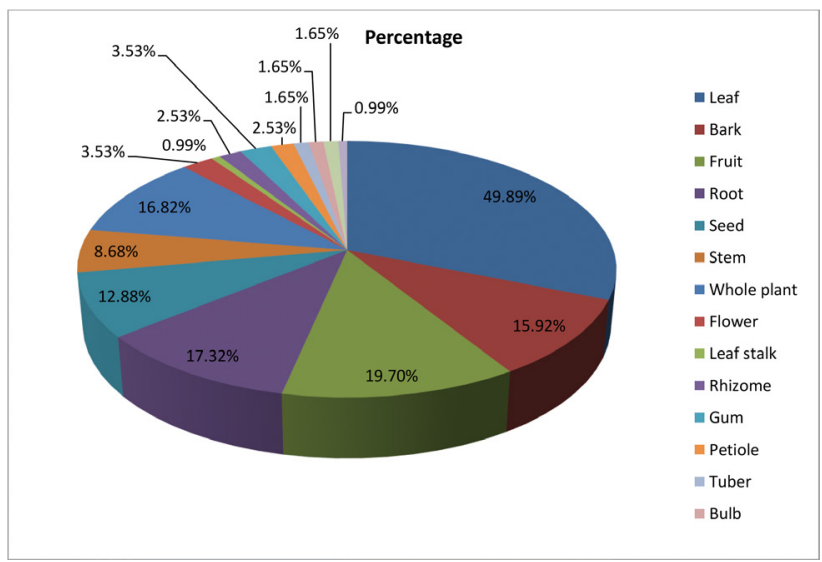

Figure 2. Recorded plant parts used as medicine

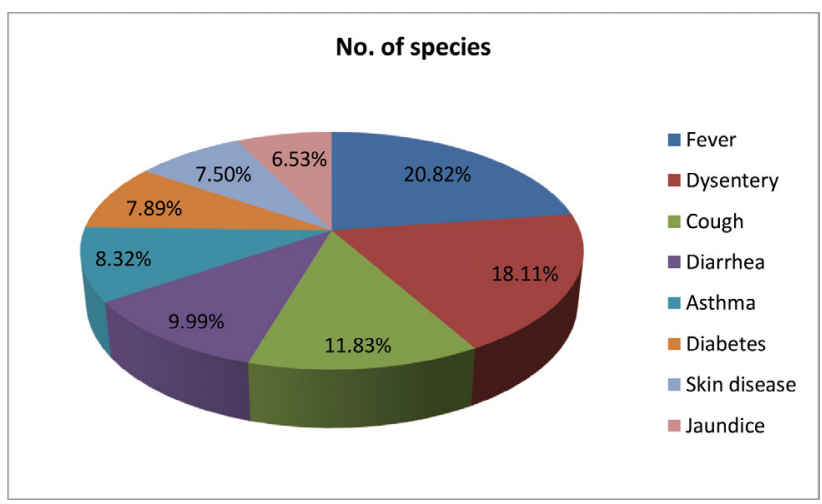

Figure 3. Investigated dominant diseases in the study area

\section{Conclusions}

The survey has recorded 66 categories of ailments of 111 medicinal species belonging to 55 families were recorded in the study area. Rural community's practitioners and older people of Rajshahi utilize a number of plant species grown around their homes for several medicinal uses. However, the younger generation by ignoring their ancestral traditional medicine is inclining towards the allopathic medicine. Since, several bioactive compounds are being extracted from traditional medicinal plants; they are in great demand in pharmaceutical industries. The photochemical an analysis and pharmacological investigations of traditional medicinally important plants by taking in view their proper conservation too, would help in developing novel drugs to treat ailments. The investigation also recorded important medicinal plants and how to use them to care for and treat various diseases.

\section{Acknowledgment}

The author is grateful to the local herbalists in and around Rajshahi metropolitan city, Bangladesh for their co-operation and help during the research work.

\section{References}

[1] Ahmed ZU, Begum ZNT, Hassan MA, Khondker M, Kabir SMH, Ahmad M, Ahmed ATA, Rahman AKA and Haque EU(Eds). Encyclopedia of Flora and Fauna of Bangladesh. 6-10. Angiosperms; Dicotyledons. Asiat. Soc. Bangladesh, Dhaka, 2008-2009.

[2] Anisuzzaman M, Rahman AHMM, Rashid MH, Naderuzzaman ATM and Islam AKMR. An Ethnobotanical Study of Madhupur, Tangail. Journal of Applied Sciences Research, 2007, 3(7): 519-530.

[3] Bangladesh Population Census (BPC) 2001, Bangladesh Bureau of Statistics; Rajshahi City Corporation 2007.

[4] Choudhury, AR and Rahmatullah M. Ethnobotanical study of wound healing plants among the folk medicinal practioners several district in Bangladesh. American- Eurasian Journal of Sustainable Development, 2012, 6(4): 371-377.

[5] Faruque MO and Uddin SB. Ethnomedicinal study of the Marma community of Bandarban district of Bangladesh. Academia Journal of Medicinal Plants, 2014, 2(2): 014- 025.

[6] Ghani A. Medicinal Plants of Bangladesh. Asiatic Society of Bangladesh, Dhaka, 2003.

[7] Guruprasad SL, Ningaiah N, Gangadhar MR. Indigenous Knowledge of Medicinal Plants among the Iruliga tribal population of Western Ghats areas, Karnataka, India.Journal of Anthropology, 2013, 9: 195203.

[8] Hooker JD. (rep. ed. 1961). Flora of British India. Vols.1-7. L. Reeve and Co. Ltd. London, U.K, 1877.

[9] Huq AM. Plant Names of Bangladesh. Bangladesh National Herbarium, BARC, Dhaka, Bangladesh, 1986.

[10] Jamila M and Rahman AHMM. Traditional Medicine Practices for the treatment of Blood pressure, Body pain, Gastritis, Gonorrhea, Stomachic, Snake bite and Urinary problems of Santal Tribal Practitioners at the Village Jamtala of Chapai Nawabganj District, Bangladesh. Journal of Pregressive Research in Biol- 
ogy, 2016, 2(2): 99-107.

[11] Khan MS. Prospects of Ethnobotany and Ethnobotanical Research in Bangladesh. In: RL Banik, MK Alam, SJ Pei and A Rastogi (eds.), Applied Ethnobotany, BFRI, Chittagong, Bangladesh, 1998, Pp. 2427.

[12] Nahar J, Kona S, Rani R, Rahman AHMM and Islam AKMR. Indigenous Medicinal Plants Used by the Local People at Sadar Upazila at Naogaon District, Bangladesh International Journal of Advanced Research., 2016, 4(6): 1100-1113.

[13] Pasha MK and Uddin SB. Dictionary of Plant Names of Bangladesh (Vascular Plants). Janokalyan Prokashani. Chittagong, Dhaka, Bangladesh, 2013.

[14] Prain D (rep. ed. 1963). Bengal Plants. Vols.1-2. Botanical Survey of India. Calcutta, India, 1903.

[15] Rahman AHMM, Ferdous Z and Islam AKMR. A Preliminary Assessment of Angiosperm Flora of Bangladesh Police Academy. Research in Plant Sciences., 2014, 2(1): 9-15.

[16] Srinivas BM. Ethno Medical Practices among the Jenu Kuruba of Karnataka. Man and Life 2010, 36(34):107-112.

[17] Yusuf M, Wahab MA, Choudhury JU and Begum J. Ethno-medico-botanical knowledge from Kaukhali proper and Betunia of Rangamati district.Bangladesh J.Plant Taxon., 2006, 13(1): 55-61.

[18] Rahman AHMM and Khatun MA. Leafy Vegetables in Chapai Nawabganj District of Bangladesh Focusing on Medicinal Value. Bangladesh Journal of Plant Taxonomy, 2020, 27(2): 359-375.

[19] Khatun MR and Rahman AHMM Ethnomedicinal Uses of Plants by Santal Tribal Peoples at Nawabganj Upazila of Dinajpur District, Bangladesh. Bangladesh Journal of Plant Taxonomy, 2019, 26(1): 117126.

[20] Khatun MM and Rahman AHMM. Medicinal Plants Used by the Local People at the Village Pania under Baghmara Upazila of Rajshahi District, Bangladesh. Discovery, 2018, 54(266): 60-71.

[21] Islam MT and Rahman AHMM. Folk medicinal plants used by the Santal tribal practitioners against diarrhea and dysentery in Tanore Upazila of Rajshahi District, Bangladesh. International Journal of Pharmacognosy, 2018, 5(6): 360-363.

[22] Kona S and Rahman AHMM. Inventory of Medicinal Plants at Mahadebpur Upazila of Naogaon District,
Bangladesh. Applied Ecology and Environmental Sciences, 2016, 4(3): 75-83.

[23] Jesmin Nahar J, Kona S, Rani R, Rahman AHMM and Islam AKMR. Indigenous Medicinal Plants Used by the Local People at Sadar Upazila of Naogaon District, Bangladesh. International Journal of Advanced Research, 2016, 4(6): 1100-1113.

[24] Rahman AHMM and Akter M. Taxonomy and Traditional Medicinal Uses of Apocynaceae (Dogbane) Family of Rajshahi District, Bangladesh. Research \& Reviews: Journal of Botanical Sciences, 2015, 4(4): $1-12$.

[25] Rahman AHMM and Keya MA. Traditional Medicinal Plants Used by local people at the village Sabgram under Sadar Upazila of Bogra district, Bangladesh. Research in Plant Sciences, 2015, 3(2): 31-37.

[26] Rahman AHMM and Gulshana MIA. Taxonomy and Medicinal Uses on Amaranthaceae Family of Rajshahi, Bangladesh. Applied Ecology and Environmental Sciences, 2014, 2(2): 54-59.

[27] Rahman AHMM, Nitu SK, Ferdows $Z$ and Islam AKMR. Medico-botany on herbaceous plants of Rajshahi, Bangladesh. American Journal of Life Sciences, 2013, 1(3): 136-144.

[28] Rahman AHMM, Sultana N, Islam AKMR and Zaman ATMN. Study of Medical Ethno-botany of traditional medicinal plants used by local people at the village Genda under Savar Upazilla of district Dhaka, Bangladesh. Journal of Medicinal Plants Studies, 2013, 1(5): 72-86.

[29] Rahman AHMM. Graveyards angiosperm diversity of Rajshahi city, Bangladesh with emphasis on medicinal plants. American Journal of Life Sciences, 2013, 1 (3): 98-104.

[30] Rahman AHMM, Kabir EZMF, Sima SN, Sultana RS, Nasiruddin M and Naderuzzaman ATM. Study of an Ethnobotany at the Village Dohanagar, Naogaon. Journal of Applied Sciences Research. Pakistan, 2010, 6(9): 1466-1473.

[31] Rahman AHMM, Anisuzzaman M, Haider SA, Ahmed F, Islam AKMR and Naderuzzaman ATM. Study of Medicinal Plants in the Graveyards of Rajshahi City. Research Journal of Agriculture and Biological Sciences, 2008, 4(1): 70-74.

[32] Alexiades MN (Ed). Selected Guidelines for Ethno Botanical Research: A Field Manual. The New York Botanical Garden, New York., 1996, 305pp. 